Article

\title{
Measure the Performance with the Market Value Added: Evidence from CSR Companies
}

\author{
Cristian Carini ${ }^{1}$, Nicola Comincioli ${ }^{2}$, Laura Poddi ${ }^{3}$ and Sergio Vergalli ${ }^{4, *}$ \\ 1 Department of Law, University of Brescia, 25121 Brescia, Italy; cristian.carini@unibs.it \\ 2 Department of Economics, University of Brescia, 25121 Brescia, Italy; nicola.comincioli@gmail.com \\ 3 University of Ferrara, 44121 Ferrara, Italy; laura.poddi@unife.it \\ 4 Department of Economics and Management, University of Brescia, Fondazione Eni Enrico Mattei, IAERE, \\ 25121 Brescia, Italy \\ * Correspondence: sergio.vergalli@unibs.it
}

Received: 4 October 2017; Accepted: 15 November 2017; Published: 24 November 2017

\begin{abstract}
An increasing number of firms in OECD countries are obtaining certification as Socially Responsible. Literature is sensitive in testing whether there is a relation between firm performance and Social Responsibility certification. In order to overcome problems related to the multiplicity of Corporate Social Responsibility (CSR) definitions and certifications, our work implements a CSR index based on the intersection between two of the three main international indices (Domini 400 Social Index, Dow Jones Sustainability World Index and FTSE4Good Index). By using this database in a panel framework, our work shows that among Corporate Performance Measures (CPF), Market Value Added (MVA) is affected by a firm's social responsible behaviour and certification. The results support the idea that CSR firms have better long-run performance. Thanks to the reputation effect, they achieve higher sales volumes and profits and a reduction in long-run costs: these effects compensate the costs due to the certification.
\end{abstract}

Keywords: corporate social responsibility; growth; market value added; firms performance; certification

\section{Introduction}

Over the past two decades in OECD countries there has been an increase in Corporate Social Responsibility (CSR, hereafter) firms that according to [1-5] can be defined as a business organization's configuration of principles of social responsibility, processes of social responsiveness, and policies, programs, and observable outcomes as they relate to the firm's societal relationships'.

CSR firms adopt ethical behavior. They are socially sensitive, that is improve workers' conditions, respect all types of diversity, allow for good governance and transparency in the management of business. At the same time they invest in the environmental field using alternative energy sources, reclaiming polluted areas, respecting biodiversity, adopting environmentally friendly fuels [6]. The relevance of CSR firms is highlighted by [7,8], "the value of assets under management in the USA that fall into the SRI category grew at annual rates of about $12 \%$ over $1995-2005$ and $18 \%$ over 2005-2007; by the end of 2007, these SRI assets accounted for $11 \%$ of total assets under professional management". Growing importance of CSR firms can also be seen by the rise of CSR reporting among S\&P 500 companies: in the years 2011-2016 they increased from just 20\% to $82 \%$. In addition, in 2015, 92 percent of Global Fortune 250 (G250) companies published corporate responsibility reporting (CR) (9). The largest 100 companies (N100) in each country surveyed increased reporting by 20 percent since 2008 to 73 percent overall, with developing nations showing fast uptake. 
Previous literature and data suggests that the growth rate of the CSR firms seems to depend on the economic development of the area referred to, and is not only time-related. It is useful to observe how the diffusion of the CSR phenomenon is not homogeneous from the geographical point of view. Sustainable indices may be a litmus test for diffusion of the phenomenon: it is not a coincidence that most of the sustainability indices arise in OECD countries. In the light of this insight, recent studies have observed that the level of economic development influences the phenomenon of social responsibility. It can be argued that the number of CSR firms has considerably increased but the highest number of CSR enterprises is from the United States and the European Union, i.e., two of the most developed areas. The number of CSR firms and their growth rates are showed in [7-12] showed the number of CSR firms and their growth rates. From this first rough observation, emerge that GDP is a crucial variable for the development of ethical conscience, and therefore CSR. Nevertheless, it should be noted that the type of index adopted is of crucial importance: use of the DJSI influences selection of the sample.

One of the main research topics related to CSR, is its impact on firms and economic system. This has been analysed by several works ([13-18]) focusing primarily on the link between CSR and the financial performance. Research suggests that financial performance prediction is sensitive to the Corporate Financial Performance (CFP, hereafter) used $([17,19])$. Therefore performance measures are divided in: (a) Market measures, such as the market capitalization measure or Beta index for riskiness of a firm; (b) Accounting measures, as ROA, ROE, ROCE. Lastly, in the most recent research, Mixed measures such as Market Value Added (MVA, hereafter) or Tobin'q measure were used. However, these studies are still limited and do not provide sufficient evidence.

Our purpose is to verify whether certain performance indicators can be affected by a firm's social responsible behavior and its certifications. The novelties of the paper are two. First of all the originality lies in its dynamic aspect and the construction of a CSR index that intersects two of the three main international indices (Domini 400 Social Index, Dow Jones Sustainability World Index, FTSE4Good Index (We used these indices also in line with previous literature, like [20-27]. Among others. Moreover about this point, as far as we know, economic research uses in general only one of these indices ([20] is the only one to use two indices).)) for an objective and a representative sample. Secondly, the paper implement jointly accounting-based measures of performance and market-based measures. Among these, the attention is on the MVA.

The main results seem to support the idea that CSR firms, which are more virtuous, have better long-run performance: even if they have initial costs due to the certification, they achieve higher sales volumes and profits, thanks to the reputation effect, a reduction in long-run costs and increased social responsible demand. Moreover we also carried out some in-depth analyses focused on particular variables, like social capital, beta financial index and reputation, finding interesting results about CSR and non-CSR riskiness.

Our paper is organised as follows: in Section 2 we summarize the literature review and in which branch our paper is positioned, Section 3 lists the main CFP and variables used in the literature and the main results formerly achieved respectively, while in Section 4 the construction of the sample is explained. Section 5 shows the data used to run our analysis. In Section 6 the aim of this study is formalized and better explained and the formal regression is explained. The complete results are shown in Section 7, while in Section 8 we carry out some detailed examinations of particular and important variables. The conclusions are contained in Section 9.

\section{Literature Review}

Literature developed extensive fields of research on issues concerning the theme of sustainability and CSR [14].

Three are the main research lines. Firstly, we can cite studies related with CSR definitions $[6,13,15,28,29]$ and CSR measurement [30]. Secondly, another field is focused on the reasons that lead firms to adopt sustainable behaviors, CSR reporting and then to obtain certification $[7,16,31,32]$. Thirdly, in the economic 
perspective, researches assess the impact of CSR on the financial system [15,16,33-35], evaluating the role of the industrial sectors as in [36-38] or focusing on single countries $([20,21,39,40])$.

As regard the first stream of study, definitions of CSR emerging in economic literature are not homogeneous [6]. Consequently, this concept is difficult to capture uniquely and correctly. Moreover, due to the fact that CSR is "not a variable and therefore it is not measurable", the economic literature has introduced the concept of Corporate Social Performance (CSP, hereafter), which is a way of making CSR applicable and putting it into practice [41]. Because of the difficulty of measuring CSP directly, many authors propose to turn it into measurable variables [15], also in line with [16], describe CSP as "a concept of three categories": CSP1: social disclosure about social concern ([17,19]); CSP2: corporate action, such as philanthropy, social programs and pollution control; CSP3: corporate reputation ratings or social indices that may be provided by social rating institutions, such as KLD, EIRIS; Fortune, Moskowitz, or ad hoc indices drawn up by the researchers themselves ([42-47]). In this regard, this paper refers to the category CSP3. Looking at previous studies, it emerges that economic research is often unidirectional and generally uses only one index. However, to overcome the problems related to the multiplicity of CSR definitions and certifications, our work builds a CSR index that intersects two of the three main international indices (Domini 400 Social Index, Dow Jones Sustainability World Index, FTSE4Good Index). In this way, empirical analysis can be conducted by using an objective and representative sample.

Looking at the second research field, related to the factors that drive companies to CSR, [16] identify different "starting points": (a) disclosure of information about social natures ([16,48-52]); (b) the reasons behind spending on social performance, such as donations, philanthropy, etc. ([7,43,52-54]); (c) a variety of principles, processes, policies, programs and observable results relating to the company's relationship with society. In this last case are defined some social indices, credit ratings provided by social institutions, such as EIRIS or KLD, or ad hoc indices drawn up by the researchers themselves $([42,44-47,55])$. On this point, many researches have been carried out on the analysis of value creation $([1,2,20,56-64])$. In order to obtain an unbiased estimate of future cash flows attributable to the firm's tangible and intangible assets, the recent work of [20] chooses firm market value, adjusted for firm size, as the dependent variable. They follow the suggestions of [64] and therefore use the market value to book value ratio, also referred to as Tobin's $Q$. The same variable is used in [65], in [66] and in the more recent [21] considering Tobin's q as a more "forward-looking" performance measure which takes into account all the growth opportunities available to firms [67].

Strictly related to this conclusion and looking at the third research area, regarding the impact of CSR on the economic system, several works ([13-18]) have analyzed the relationship between CSR and the financial performance of the certified firms. About this, research shows that there is a difference in the prediction of financial performance by using different CFP ([17,19]. According to van Beurden [15] CFP are distinguished into two categories: market-based measures (CFP 1) that include stock performance, market return, market to book value, price per share, share price appreciation and other market based measures; accounting-based measures (CFP 2) such as ROE, ROA, ROCE and many financial indicators drawn up on the basis of book accounting. Summing up the huge literature about these impacts, many meta-analysis studies have been carried out [17,68-70]. These works generally endorse the argument that there is a statistically significant positive relationship between the financial performance and Corporate Financial Performance (CFP) measures though the magnitude of the observed link remains low. Analysis of the previous works suggest that further research is required.

Positioning in the field of studies based on Corporate Financial Performance measures $[17,19]$ and using the definitions of van Beurden [15], this paper tests some indicators of financial performance, primarily focusing on the Market Value Added (MVA hereafter), as a summarizing indicator. 


\section{Corporate Financial Performance Measures}

Economic literature classifies the variables representing performance into market and accounting measures. We summarize the variables useful for reaching our goal and that belong to both these sets:

1. Market Measures: (a) MKTCAP (It is the most important market-based performance measure with a huge amount of literature: $[48,56,61,71-74])$. (Market Capitalization) measures the market capitalization that defines the value of a firm; (b) Beta (It is a content of the CAPM (Capital Asset Pricing Model, see: [74-77]) and its importance has become one of the best known variables in investing and finance. Its main references are: [40,56,78]): describes the relation between the expected return of the whole market and the expected return of a financial portfolio (or a single stock). Its value represents also a risk measure: when its value is lower than one unit, the considered asset is likely to reduce the market fluctuations, while the opposite happens when its value is higher than 1 . The economic literature shows that firms with high systemic risk use social certification to reduce their exposure risk: therefore, their beta coefficient reduces (see: $[50,78]$ ). Richardson et al. and Botosan $[79,80]$ show that the reduction in the exposure to risk can also reduce the cost of capital and accordingly information asymmetries, thanks to the increased social information.

2. Accounting measures: (a) ROE (One of the most widely used performance measures (see: $[1,2,21,78,81-86])$. It is defined as the percentage of the yearly net income of a firm (before common stock dividends and after preferred stock dividends) with respect the total equity (excluding preferred shares), and corresponds to the rate of return of the shareholders invested risk capital.): this measure is useful to estimate the profitability of a firm, that is its efficiency in generating earnings from every dollar/euro of net assets (assets minus liabilities); (b) ROA (See $[1-3,48,87,88])$ : describes "what the company can do with what it has got", i.e., how many euros of earnings it can obtain from each euro of assets. Its average value strongly depends on the economic sector analyzed, so it could be useful to compare the profitability of the companies of the same industry; ROCE (This measure is commonly used to compare the performance between different businesses and to verify if the generated return is sufficient to pay back the cost of capital. It is defined as the pre-tax operative profit divided for the employed capital. See [1]: in finance it measures the return that a company is generating from capital employed.

3. Mixed Measures: Market Value Added (MVA). Firstly introduced by Simerly et al. and Cochran et al. $[89,90]$, is defined as the difference of the current firm market value and the capital contributed by investors, as of the balance sheet. A positive MVA means added value in the company while distinguishing negative MVA that have destroyed value. This is a mixed measure because it combines both market and account values. MVA can also be seen as a manner to introduce the Tobin's q, as in Shahzad et al. [65]. Bharadwaj et al. and Konar et al. [62,63] suggest that standard accounting measures of performance, such as (ROA) return on assets, lack in their ability to evaluate the future profit potential of such practices. To overcome these limitations some papers $([20,21,64,66])$ consider the Market Value Added as a key variable of research.

\subsection{Further Important Variables}

Economic literature show further variables to investigate the relationship between firms performance and CSR certification:

1. Industrial Sector. According to Dierkes et al. [91], those firms whose economic activities are involved in the exploitation of natural resources (mining, forestry, oil, gas and so on) or that affect the environment are subject to stronger environmental controls than those of other sectors. So, industrial sector could be important for CSR. Furthermore some enterprises with a strong relation with consumers need to show a clear social behaviour, in order strengthen the firm's reputation and achieve positive effects on the sales volumes (see: [85]). Moreover, in Patten et al. (1991) [92] the authors explain that the industrial sector (as a proxy of dimension) 
affects the "fame policy" of a firm, forcing the management to take public opinion into account ([48]). Finally, this varable has effects on the number of enterprises belonging to the CSR group: low-labour intensity sector (i.e., banks, financial services, etc.) show higher number of firms than high capital intensity sectors.(About this, see [2]) Capelle-Blancard et al. [93] shows an interesting approach that takes into account the different weights of industrial sectors: the authors proposes an original weighting scheme, reflecting societal concerns and depending on sectors.

2. Size (Economic literature show different manners to measure firm size: by using the total asset value, or the number of employees, or the total sales. Belkaoui et al. [48] use the natural logarithm of the sales net value, while Spicer et al. [78] use both the total asset value and the sales value. Cowen et al. and Patten [85,92] also use the natural logarithm of sales the Fortune 500 index. Kimberly et al. [94] show that all these measures are strongly correlated and quite similar.): Waddock et al. [2] write that it is possible to assume that as the size of a firm increases, so does its behaviour to act responsibly. This should happen because big companies are more conscious of the importance of their relationship with the public (and external stakeholders) than the smaller ones. The work of Dierkes et al. [91] confirm that the size can affect the firm performance and social certification link: at the beginning the firm strategy is focused on basic survival, while the focus changes to its philanthropic and ethical responsibilities as its size increases.

3. Age of Capital. Roberts [95] assumes that the firms historically highly involved in social investment have a greater induced reputation, making the stakeholders more confident about the expected profits. Wood [96] measure the capital age as gross and net capital: the firm is relatively young when this index tends to 1 . Therefore the age of capital is inversely correlated with the CSR variable: the younger the enterprise, the higher the ethical investment. It is interesting to stress that it is more expensive to change a firm's structure than to create a new one and that new firms do not have transformation costs for new lines of production.

4. Intangible Assets Expenses. Even if economic literature is strongly focused on R\&D expenses, this variable if very close to the total expenses (also considering costs related to the CSR index). Indeed, $R \& D$ is a subset of total intangible assets and could also be their proxy variable. In McWilliams et al. (2001) [3] the authors show the correlation between the financial performance and the CSR index. Indeed innovation and R\&D expenses are some of the main variables that can affect economic growth in the medium-long run. Moreover, R\&D expenses are sometimes used as a proxy for social certification.

5. Leverage. It is defined as the total debt and shares ratio. Myers and Wallace et al. [97,98] have shown a positive relation between CSR index and the leverage. (CSR index is defined by social disclosure, that is social information). Jensen et al. [99] supported this result by explaining that a firm tends to increase its social information in order to reduce rising monitoring costs from high leverage. Ahamed et al. [100] show a similar explanation, stressing that as the weight of the bond in the balance sheets increases at the expense of the ordinary stocks, so does importance of the social information and social certification. Roberts [50] did not find any statistical evidence in the test of the hypothesis that the higher a firm's leverage, the higher creditors' expectations. However, Belkaoui et al. [48] showed negative correlations.

\section{The Sample}

In order to avoid redundancy of CSR certified firms literature presented in the previous paragraphs suggests two solution. The first one is to identify the best (most influential) rating agencies and take only the criteria that they express. The second one is to use multiple assessments, so that the certification of a firm can be confirmed by several rating agencies. In our opinion, the most powerful way is to combine the two solutions, that is use multiple evaluation criteria characterized by good quality $([11,12])$. 
Therefore, our paper's first goal consists in defining a database of CSR firms that combine more than one certification index. In detail, we selected the firms for our sample following the steps below:

1. We selected the CSR firms belonging at least to two of the three main stock option indices of the market in 2004: Domini 400 Social Index, Dow Jones Sustainability World Index, FTSE4Good Index. The indexes were selected because they are the most famous and recognizable indices at an international level. Implementing methodology used by Poddi et al. and Barnea $[10,101]$, the CSR sample consists of 317 firms.

2. In order to build the control sample, we chose 100 non-CSR firms from the Dow Jones Global Index. Sector stratification was implemented to make the Non-CSR sample homogeneous with the CSR sample. For each sector, firms were randomly selected.

3. The final sample consist of 417 firms. In order to generate the time series, we started with the last year of our sample, and maintaining the total number of firms we worked backward until first one, changing the non-CSR/CSR ratio. Dummy variable for each year were created starting from the last year ( 1 if that firm was certified as a CSR firm in that year and zero otherwise). The finale sample results from the intersection (for a couple of sets) of the three indices. (We were not able to work further back than 1999 because the CSR firms available in our database were not sufficient)

We downloaded the balance sheets of all 417 firms. We use Perfect Analysis software because contains the panel data of the stock prices, the level of dividends, and also other financial information about firms' balance, exchange rates and market indices. Moreover, it contains the main OECD economic indicators.

\section{Data}

We collected the following performance variables about 417 enterprises for five years by using the Perfect Analysis database and referring our previous paragraphs: ROE and ROCE (We adopt ROCE as a variant of the more common ROA, due to the greater compatibility of data.); MKTCAP (From Perfect Analysis, in the budget reports of each company- "Fundamentals" sheet; voice "Market Cap".), MVA (We follow the following methodology and use Perfect Analysis database to build this performance indicator: the company's market share value was estimated referring to July 2004 and multiplied by the number of shares at the closing share price on 31 December of each year (from 1999 to 2003). The Yahoo Finance website was the source for historical stock prices. The "stockholder's equity" is then subtracted from the equity market value in the social balance sheet of each company. We can therefore compare the economic value of stakeholders' equity (MV) and its book value, and then the market (and therefore stakeholders) can evaluate the business in place or in the future.).

Each company differs from another one in implementing CSR. These differences depend on many factors such as, for example, the corporate culture, stakeholders' demand, the particular sector in which it operates, the enterprise's size and historically how progressive the company is in achieving CSR.

Some companies specialize in a single area, where they have the greatest impact or vulnerability (i.e., environment or human rights) or which they consider the most important; while other companies would like to integrate CSR into all aspects of their operations.

Other variables are as follows: (a) AGE (Data source: Perfect Analysis—“Property, Plant and Equipment-Total (Gross)" and "Property, Plant and Equipment-Total (Net)". The expectation against the use of this variable is defined as: "The latest companies behave more responsibly" [96]) is the ratio between the net value and gross assets in property, buildings and equipment. The more this ratio tends to a value of one, the newer the company is; (b) INTA (Source: Perfect Analysis- "Intangible Assets-Total".) (Intangible Asset) annual expenditure on intangible heritage, namely copyrights, patents, intellectual property and know-how. Intangible spending drives performance and can easily be used as an instrumental variable (See [7,102] (among others) about endogeneity problems.), which is also strongly correlated to CSR; (c) STLT (Data source: Perfect Analysis-"Common Size "ST Debt 
(\% of Assets)" and "LT Debt (\% of Assets).") (Short Term Debt/Long Term Debt) is the ratio between short-term/long-term debt; (d) INTE In the Perfect Analysis database-_profits and losses",-_data were collected on the number of employees under the heading "Employees Units". For total assets: balance sheet "total assets".) (intensity of work): number of employees and total assets ratio; (e) Size. Calculated by using the total sales, as Stanwick [51], Cowen et al. [85] and Fombrun et al. [103]; (f) Risk. On the relation between belonging to a CSR group and risk points out how it can be quantified through the Beta index for each of the 417 companies of the sample, compared to 2004 for cross section analysis. One important caveat about our future analysis is about the link between the possible company risk and economic management. Socially responsible behaviour aims at reducing environmental organizational and operational risk. Nothing is said about financial risk, even if it adopts the Beta index. This discrepancy creates different results and comments on risk assessment; (g) Reputation. We use a reputation quotient published by the Reputation Institute (Reputation Institute-www. reputationinstitute.com-www.harrisinteractive.com), based on a survey on the more visible American multinationals. In detail, each company was assessed by over eighteen random factors selected by the company's policy. The respondents associated a score based on 20 attributes relating to six key dimensions: (a) Vision and leadership; (b) Work environment; (c) Financial performance (d) Products and services; (e) CSR; (f) Emotional appeal. The index is explained for a sample of firms from five years; (g) Critical Demand, D (Taken from a research carried out by MORI (Market and Opinion Research International). MORI (Market and Opinion Research International)—www.mori.com). The literature justifies a sales increase from a differentiation on the market supply. The critical consumers satisfy their needs with particular goods characterized by improvement or environmental respect of labour conditions; (h) Social Capital (Source: the IVIE (Instituto Valenciano de Investigaciones Económicas) database. Instituto Valenciano de Investigaciones Economicas-www.ivie.es). Data on Social capital indicators can be useful to understand the change in the individual's choice (and therefore total demand) due to critical behaviour. In literature, the social capital concept has evolved from initially purely sociological definitions ([104,105]) to broader meanings including civic sense [106], cooperation between individuals and compliance with the law ([107-109]). So, social capital could be considered a proxy of individual behaviour and, therefore, could be considered a useful variable; (i) GDP: data from the World Bank database.

\section{Empirical Analysis}

\subsection{Correlations among Variables}

In Table A1 in Appendix A we show some correlations among variables. Our main results show that the following couple of vairables are positively correlated: expenses in intangibles and size; MVA and CSR; MVA and size; CSR and size; CSR and intangibles; intangibles and the age of the firms. Therefore bigger firms correspond to higher values and given that more business meant better performance for investors, and given the link size-sales, then also SIZE-MVA relationship is confirmed. FInally, the expenses in intangibles of the most recent firms are higher, due to the start-up procedure that includes innovation technology costs, copyright, and R\&D.

\subsection{The Regression Model}

To study the relationship between profit or the economic performance and CSR we use the following linear regression model:

$$
\Pi_{i c t}=\alpha+\beta_{1} C S R_{i c t}+\beta_{2} S I Z E_{i c t}+\beta_{3} I N T E_{i c t}+\beta_{4} S T L T_{i c t}+\beta_{5} D_{c t}+X_{c t}^{\prime} \gamma+\eta_{c}+v_{t}+\varepsilon_{i c t}
$$

where $\Pi$ is the dependent variables and represents the economic performance (using MVA, or the $\mathrm{ROE} / \mathrm{ROCE}$ variables) for each firm (i), in country (c) and year (t). While our regressors are the following independent variables: (a) CSR; (b) SIZE: a categorical variable in which we calculated firm size by using the amount of sales. In details, 1 means small enterprises, 2 for medium enterprises and 3 
for the biggest one; (c) INTE: corresponds to the intensity of work and is the number of employees and the total asset ratio; (d) STLT: long and short-term debt ratio; (e) D: the critical demand (This variable uses MORI work about UK demand and readjusts for each country.), (f) $\mathbf{X}^{\prime}$ : the gross domestic product per capita for year $\mathrm{t}\left(\mathrm{x}_{t}\right)$ and lagged value $\left(\mathrm{x}_{t-1}\right)$. Finally, the regressions take also into account fixed effects of: time $\left(v_{t}\right)$ and geography $\left(\eta_{c}\right)$.

As in our previous paper (see [11]) even if we performed the regressions over all the variables, we show only the most significant results. In the next parts we will show results about peculiar regressions carried out for some variables but we focus our analysis on the MVA, because Table A1 in Appendix A and our regressions confirmed that it is the only significant performance variable.

Our goal is to test the sign and the magnitude of regression Equation (1) over a 5-year period but before running it, we have investigated the some possible endogeneity problems. In details, endogeneity may depend on the higher resources of the best performing firms useful to enter the social index. Vice versa, a CSR firm with a high reputation could improve its market evaluation. We test the endogeneity problem by using Granger and Hausman test. Both Granger and Hausman do not show endogeneity problem (See [11,12] for details. In details, Hausman results confirm 4 out of 5 cases with no endogeneity.). To be sure of avoiding this problem, we run our regression with INTA and AGE as instrumental variables for CSR.

\section{Results}

The main results of the panel analysis are exposed in Table 1.

Table 1. Regression Models.

\begin{tabular}{|c|c|c|c|c|c|c|c|c|c|c|c|c|}
\hline \multirow{2}{*}{ Model } & \multicolumn{2}{|c|}{1} & \multicolumn{2}{|c|}{$2 a$} & \multicolumn{2}{|c|}{$2 b$} & \multicolumn{2}{|c|}{$3 a$} & \multicolumn{2}{|c|}{$3 b$} & \multicolumn{2}{|c|}{4} \\
\hline & $\beta$ & $\mathrm{z}-$ & $\beta$ & z- & $\beta$ & z- & $\beta$ & z- & $\beta$ & z- & $\beta$ & z- \\
\hline Int. (a) & $\begin{array}{c}-1.3 \\
(* *)\end{array}$ & -2.1 & $\begin{array}{c}-1.6 \\
(* *)\end{array}$ & -2.3 & $\begin{array}{c}-1.4 \\
(* *)\end{array}$ & -2.4 & -0.42 & -1.4 & $\begin{array}{c}-0.04 \\
\left.{ }^{*}\right)\end{array}$ & -1.8 & $\begin{array}{c}-0.9 \\
\left(^{*}\right)\end{array}$ & -1.8 \\
\hline $\operatorname{CSR}(a)$ & $\begin{array}{c}-0.3 \\
(* *)\end{array}$ & -2.5 & $\begin{array}{c}-0.3 \\
(* *)\end{array}$ & -2.6 & $\begin{array}{l}-0.3 \\
(* * *)\end{array}$ & -2.7 & $\begin{array}{c}-0.35 \\
(* *)\end{array}$ & -2.6 & $\begin{array}{c}-0.35 \\
(* * *)\end{array}$ & -2.6 & $\begin{array}{c}-0.32 \\
(* *)\end{array}$ & -2.2 \\
\hline SIZE(a) & 0.03 & 1.6 & $\begin{array}{c}0.05 \\
(* *) \\
\end{array}$ & 2.0 & $\begin{array}{c}0.04 \\
(* *)\end{array}$ & 2.0 & $\begin{array}{c}0.04 \\
(*)\end{array}$ & 1.9 & $\begin{array}{c}0.04 \\
\left({ }^{*}\right)\end{array}$ & 1.9 & 0.03 & 1.4 \\
\hline$x_{t}$ & $\begin{array}{l}47.6 \\
(* *) \\
\end{array}$ & 2.2 & $\begin{array}{c}54.5 \\
(* *) \\
\end{array}$ & 2.3 & $\begin{array}{l}49.0 \\
(* *)\end{array}$ & 2.4 & 15.8 & 1.5 & & & & \\
\hline $\mathrm{x}_{t-1}$ & & & & & & & & & & & $\begin{array}{c}33.7 \\
(*)\end{array}$ & 1.9 \\
\hline INTE & & & 327.2 & 0.44 & & & & & & & & \\
\hline STLT & & & $\begin{array}{c}0.0004 \\
(*)\end{array}$ & 1.8 & $\begin{array}{c}0.0004 \\
\left({ }^{*}\right)\end{array}$ & 1.79 & $\begin{array}{c}0.0004 \\
(*)\end{array}$ & 1.7 & $\begin{array}{c}0.0004 \\
\left({ }^{*}\right)\end{array}$ & 1.7 & $\begin{array}{c}0.0004 \\
\left({ }^{*}\right)\end{array}$ & 1.7 \\
\hline $\mathrm{D}(\mathrm{a})$ & & & & & & & $\begin{array}{c}24.4 \\
(* *)\end{array}$ & 2.0 & $\begin{array}{c}31.2 \\
(* *)\end{array}$ & 2.3 & $\begin{array}{c}15.3 \\
(*)\end{array}$ & 1.7 \\
\hline $\bar{R}^{2}$ & 0.78 & & 0.717 & & 0.72 & & 0.725 & & 0.725 & & 0.858 & \\
\hline
\end{tabular}

MVA dependent variable, where $\bar{R}^{2}$ is the adjusted $R^{2} ; \beta$ is the coefficient value; " $z-$ " is the $\mathrm{z}$ stat with significance: $\left({ }^{*}\right) 90 \%$ Significant; $\left({ }^{* *}\right) 95 \%$ significant; $\left(^{* *}\right)$ 99\% significant; (a) all the data are divided by one million.

Following regression 1 we detect that that MVA decreases when CSR increases. To explain this firs result we refer to the follow steps. Firstly, model 1 analyse the magnitude of MVA average changes when a firm starts to belong to the CSR group. Secondly, looking at our previous papers [11], we know that a CSR firm has a higher MVA and our expectation is a positive relationship between MVA and CSR behaviour. Thirdly, the interpolation analysis evaluates the average level of MVA and does not 
distinguish between the CSR and non-CSR groups, even if the MVA is higher for CSR firms. Finally, MVA decreases over time but the number of CSR firms increases. This causal chain, explains why the sign between the two variables is negative. The coefficient shows how much MVA changes depending on the variation of CSR percentage in the sample: more CSR means that some firms have moved from one group to another one. These companies left the no-CSR group characterized by a low MVA level and gone to the CSR group with high MVA. On the consequence, the average MVA has decreased.

Model 1 find out a second important result that is an increase in MVA with the rise in GDP per capita. This is not surprising because when GDP increases there are more resources for further investment and the result confirm previous literature that highlight a relationship between CSR and GDP.

The variable SIZE is not significant. In addition, it seems to show contradictory evidences also because it is not so obvious that a higher amount of sales implies better market evaluation, especially during negative situations.

The regression model 2a introduces the INTENSITY and STLT variables: the last one is significant. Concerning the signs of CSR and GDPPRO, the explanations is the same given for model 1. Variable INTENSITY is not significant. This result suggest that firms' structure does not affect the CSR index. Indeed, we cannot predict that a firm with low intensity has a lower $\Pi$. Looking at STLT, a positive sign means that the short and long-term debt ratio tends towards a higher percentage of short-term debt. This result suggest us that investors could prefer to buy shares because they expect an increase in the profitability in the long term.

Looking at model $2 \mathrm{~b}$ and model $3 \mathrm{a}$, our first comment stresses that MVA is both a premium of a firm's strategies and represent a predictor of the firm's profitability, in the case of perfect asset evaluation. At a first stage, increased GDP per capita means higher consumption and therefore higher sales, but not necessarily higher wealth mean more spending on ethical products.

In order to understand how product differentiation of CSR firms affects $\Pi$ we include in model 3 variable "critical demand". Our results suggests that this variable is closely related to GDP per capita: as we have stressed by referring to economic literature, CSR firms are concentrated in the most developed countries. To confirm that critical demand tends to rise in OECD countries, we introduced a causality test, showing that GDP per capita implies DEMAND. After our digression, model 3 clearly shows non-significant GDP per capita: its effect is caught by DEMAND. $R^{2}$ value and the significance of DEMAND seem to support our model, even if the constant is not significant. Starting from this conclusion, we obtain the following model $3 \mathrm{~b}$ in which the $R^{2}$ value and the significance of all coefficients show that the model is our best one. Nevertheless, a high GDP pro capita implies a development of a critical demand and therefore lagged GDP per capita could affect MVA, as shown in model 4 in which SIZE is not significant. Anyway, in all cases SIZE does not show clear and univocal results.

\section{Close Examinations}

\subsection{CSR and Beta}

The purpose of this paragraph is to provide an in-depth analysis of business risk. We have tried to understand if there is a link between RSI and risk. To do this, we divided the entire sample (417 companies) into quartiles, using the beta of 2004. The first quartile contains $25 \%$ of the observations belonging to the range $[-0.02 ; 0.68]$, which corresponds to less risky enterprises characterized by a lower beta level than the benchmark case (market level 1) and low volatility. On the contrary, the last quarter includes the most risky enterprises (The Beta index is a market share index that considers speculative risk. It could be assumed as an index of working risk under the assumption of perfect markets.).

The Table 2 shows the number of CSR and non-CSR enterprises belonging to the first and fourth quartile, i.e., the least (Nrisk) and the most risky (Risk), for the years between 1999 and 2004 (It is 
worth noting that nothing can be said about the dynamic impact of the certification on risk: indeed we have only the Beta index of the year 2004.).

Table 2. Number of CSR and non-CSR enterprises, belonging to the first and fourth quartile.

\begin{tabular}{cccccccc}
\hline CSR & $\mathbf{1 9 9 9}$ & $\mathbf{2 0 0 0}$ & $\mathbf{2 0 0 1}$ & $\mathbf{2 0 0 2}$ & $\mathbf{2 0 0 3}$ & $\mathbf{2 0 0 4}$ & TOT \\
\hline Nrisk & 34 & 37 & 46 & 59 & 65 & 71 & 112 \\
Risk & 42 & 48 & 62 & 71 & 78 & 82 & 102 \\
\hline NCSR & $\mathbf{1 9 9 9}$ & $\mathbf{2 0 0 0}$ & $\mathbf{2 0 0 1}$ & $\mathbf{2 0 0 2}$ & $\mathbf{2 0 0 3}$ & $\mathbf{2 0 0 4}$ & TOT \\
\hline Nrisk & 78 & 75 & 66 & 53 & 47 & 41 & 112 \\
Risk & 60 & 54 & 40 & 31 & 24 & 20 & 102 \\
\hline
\end{tabular}

The results we now illustrate are related to the static analysis of variables, focusing on the number of companies in different groups (Our implicit assumption is that we keep the intervals fixed.).

The comparison shows that the total number of Nrisk companies is higher than the risky one, while the number of CSR enterprises is higher in the case of Risk (and also has a higher percentage). The emerging outcome is unexpected, in fact there is a high share of risky CSR companies. Indeed, $[18,78,110]$ found that "risky firms use CSR to reduce their risk" and therefore, in line with this result, a lower number of CSR firms in the risky group was our expectation. About this:

(1) A high volatility of the shares may be due to an economic shock and may involve a beta value greater than 1 .

(2) In a perfect market environment, investors can perfectly predict the value and risk of the investment. Given the importance of this index, it is important and correct to evaluate in depth the total distribution of companies compared to the Beta index (Figure 1):

(i) we have a higher number of non-risky enterprises, due to a positive (right) asymmetry of distribution;

(ii) the average Beta is higher than 1 and this implies that in our simple there are some risky firms certified as CSR (i.e., outlier cases). This beta value is sufficiently high to move the distribution to the right.

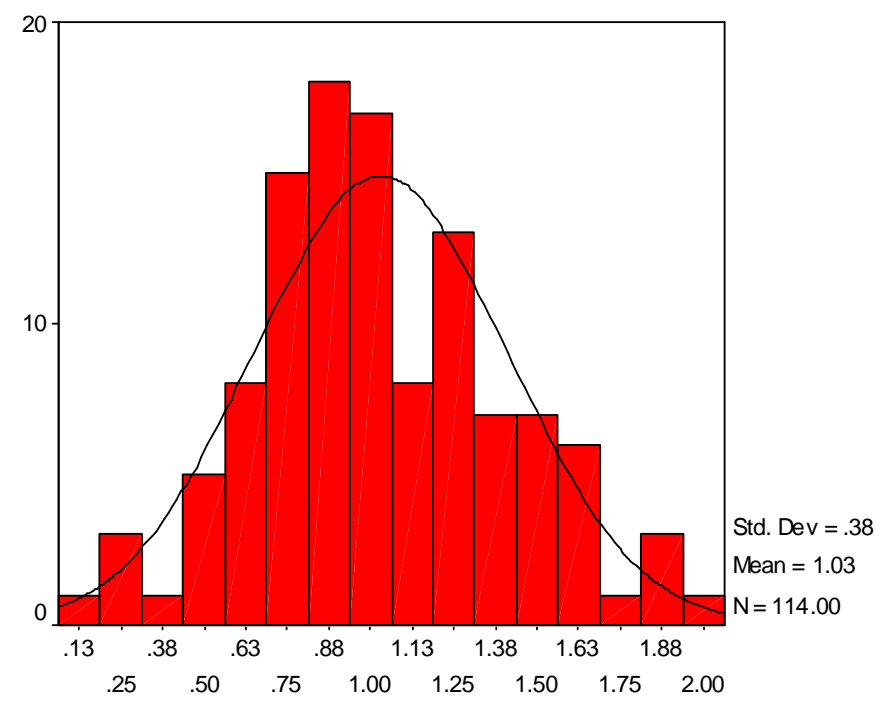

BETA04

Figure 1. Total distribution of enterprises with respect to the Beta index. 
In this context, the strategic choice of management might be to obtain certification in order to reduce the risk (as in [111,112]). In this case, however, the effect should be medium-long, so we should wait to see the results and effects. The fundamental discovery should cover the year considered and the period when virtuous behavior began. Therefore our results are aligned with the economic horizon and underline how the search should focus on investment timing and business heterogeneity in order to understand the relationship between CSR and risk. To conclude, from the fourth quartile it might emerge that risky companies are likely to become more responsible. Therefore, we believe that the effects of responsible social behavior will be verifiable in the medium to long term.

\subsection{A Comparison between MVA, Beta and CSR}

In Table 3 and Figure 2 we compare the average MVA level among risky and non-risky firms, finding that a firm with highly volatile shares always has a higher profitability, regardless of whether it is CSR or not.

Table 3. MVA comparison level among risky and non-risky firms.

\begin{tabular}{cccccc}
\hline & MVA99 & MVA00 & MVA01 & MVA02 & MVA03 \\
\hline RISK_CSR & 52,318 & 36,532 & 22,343 & 10,618 & 18,110 \\
RISK_NCSR & 52,460 & 33,152 & 21,956 & 10,624 & 19,248 \\
NRISK_CSR & 13,332 & 12,214 & 11,419 & 9182 & 11,134 \\
NRISK_NCSR & 10,840 & 10,740 & 10,323 & 8972 & 10,849 \\
\hline
\end{tabular}

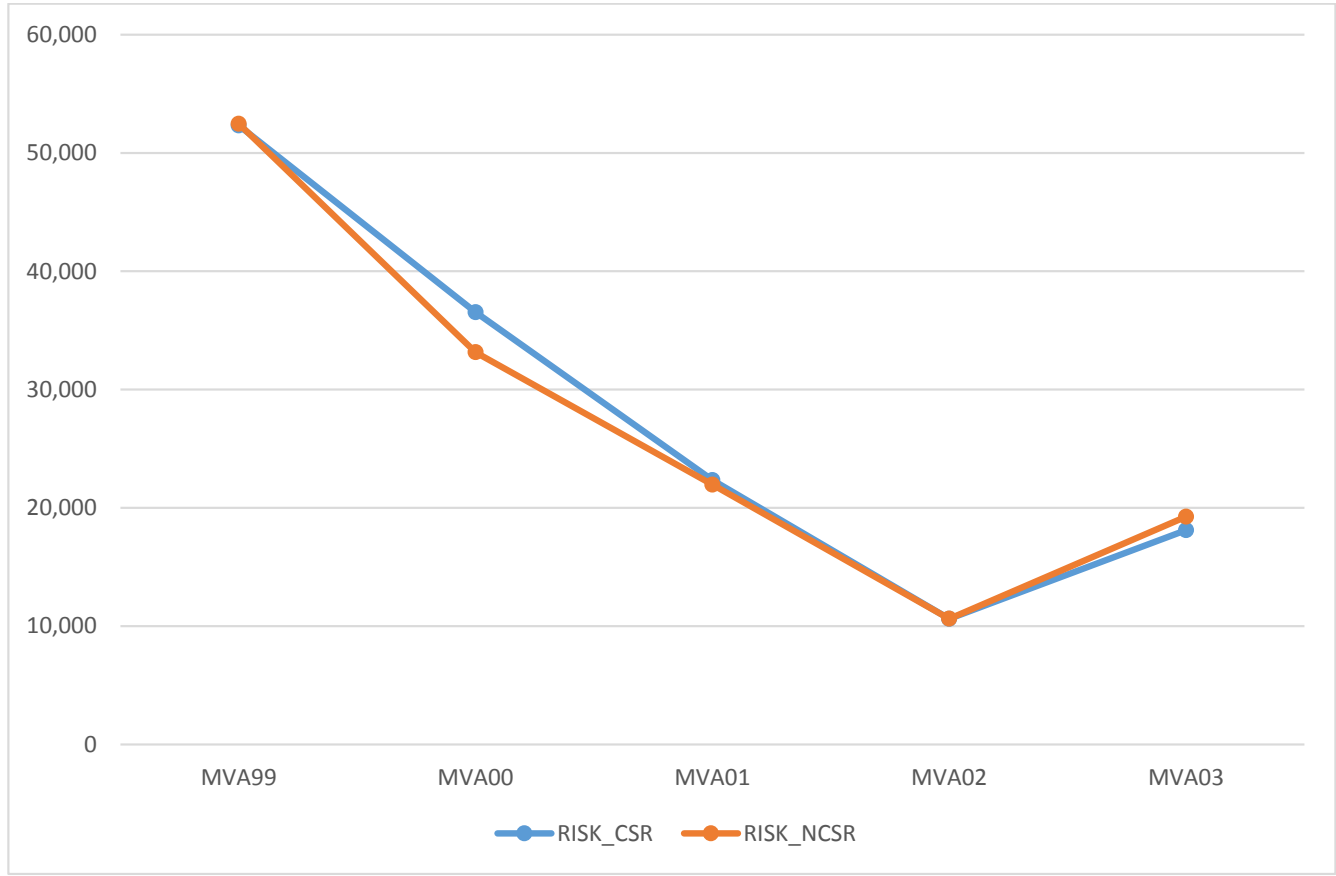

(a)

Figure 2. Cont. 


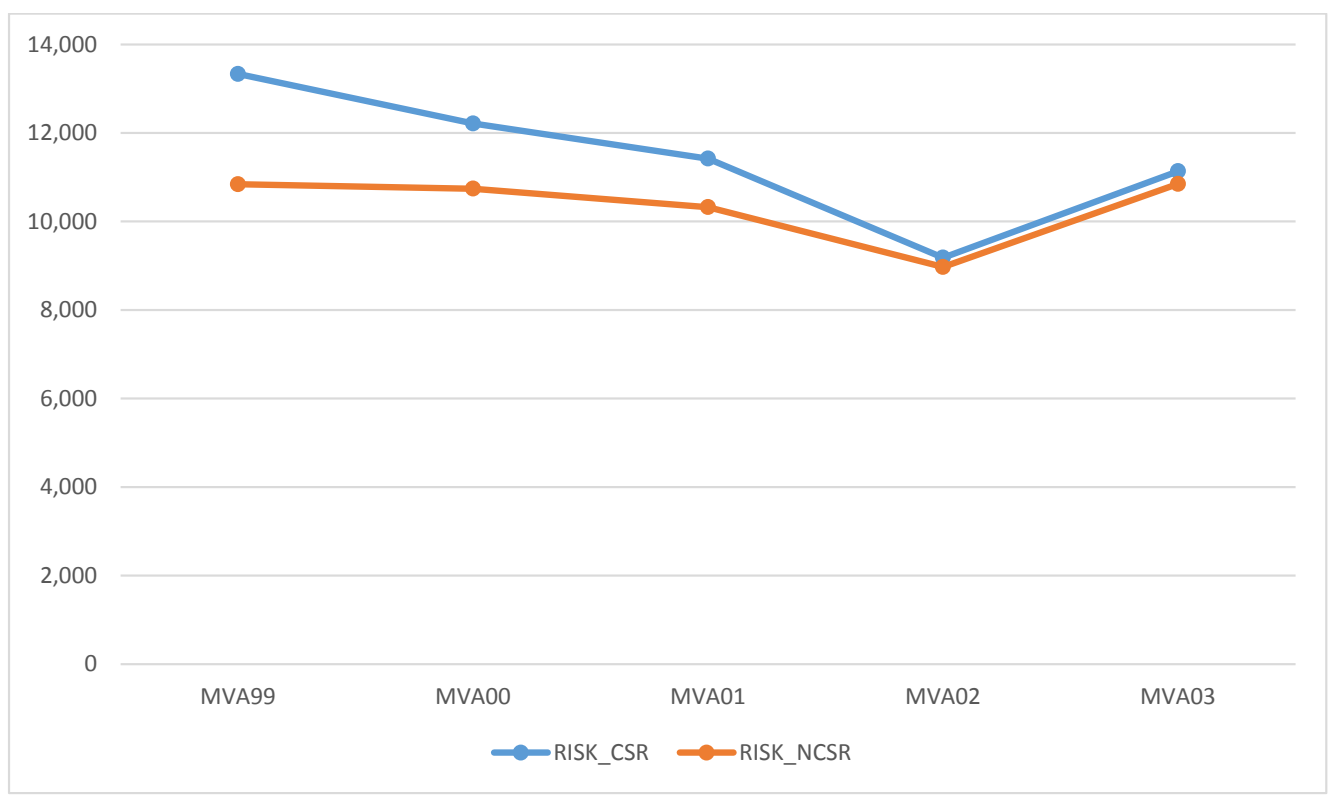

(b)

Figure 2. MVA comparison level among risky and non-risky firms. (a) MVA comparison level among risky firms; (b) MVA comparison level among non-risky firms.

We know that MVA is not CSR is lower than MVA_CSR, but from Figure 2 we can see that in the last quartile there are fairly similar values. How can we show that the value of non-CSR MVA is equal to CSR? Looking at the results shown in Table 3, we notice in the distribution center the highest difference in MVA values. Let's try to understand the reason. A first motivation may depend on a short-term effect of the CSR investment. If, as we have noted, adopting virtuous behavior is a management choice to reduce long-term risk, the fourth quartile could include newly certified CSR companies. In this case there are no differences between CSR and CSR companies. The only difference is a formal certification that takes time to act.

Additionally, if the quartile consisted of a normal Gaussian distribution of new and old CSR enterprises (then distribution according to the age of RSI enterprises), then we will have virtuous and non-virtuous effects that could counterbalance each other. In addition, short-term certification costs could reduce the MVA level. At the same time, adopting virtuous behaviors, with the ability to improve performance and reduce risk, could increase MVA (Belonging to the fourth quartile could be due to a specific risk or short adoption timing.).

The two effects combine, and so non-CSR values equal the CSR ones. About the central quartiles, we notice that a higher MVA level for CSR may depend on the age of the firms. In this case a higher MVA and a lower volatility could depend on the investors' premium that has been "metabolized".

Finally, addition of the Beta variable entails a change in stock perception: for non-risky firms, it is better to be CSR while if the firm is risky, it makes no difference.

\subsection{Industrial Sectors}

A further important element to analyse CSR companies is the role-related industries. In order to obtain CSR certification, a company has to adopt "virtuous" and costly behaviours in the organisational structure of the company, both for ethical and negative environmental externalities and also to reduce detrimental action of ethical principles. Therefore we can assume that it is more easy to certify as CSR companies which by their nature are less involved in potentially harmful activities, such as banks. At the same time, some companies have some problems in this as their activities are by definition 
less sustainable than others and must bear higher costs that reduce the company's profitability, e.g., oil companies.

We can therefore compare sectors in our sample, in order to discern the sector impact of CSR. However, it is difficult to see significant peculiarities in the two groups, as the control sample was specifically homogeneous for the industrial sector, in other words there is an implicit difference between the two groups, for sector composition. Therefore, results derive from our descriptive analysis (see [113]).

\subsection{Reputation}

In economic literature, the concept of reputation seems to be fundamental for the effects of CSR. The basic idea consists in defining reputation as synthesis and a consequence of a strategic business choice $([1,21,50,85,114-117])$. Consumers and investors could perceive the choice to become CSR as a sign of possible future performance. Corporate reputation is identified as one of the keys to competitive success and is defined as the firm's image, built over time by the different interest groups ([118-120]). As it is a source of possible long-term competitive advantages, CSR is could be one of the firms resources to reach a better corporate reputation [121]. The empirical papers of [3,44,103,121-125] stand out for having verified the benefits associated with a good reputation. We have also observed that investors do not reward this choice with a higher average MVA. Therefore, we tried to implement this variable into our model given its importance.

We used data from the Reputation Institute, as shown previously. At least theoretically, as we have explained in this paragraph, given that the CSR variable is one of its fundamental elements, we expect a strong relationship between CSR and the Reputation Index. However according to empirical evidence, the reputation index is not significant, highlighting either a combination of internal weights or errors of its empirical model (We must stress that financial performance could be another key variable in building the reputation quotient. Therefore In order to find why it is not significant, in our previous discussion paper [11], we projected data relating to financial data and reputation. We have shown that the Reputation Index is almost completely weighted on financial variables.).

\subsection{Social Capital}

In order to introduce possible future research focused on critical demand, we introduced a possible proxy of sustainable behaviour: social capital in a country as explanatory variable. This is an index that summarize other measures, as the number of associations and donations within a community and should provide the altruism level in a given geographic area. The most interesting result is that by entering DEMAND, GDPGRO, SIZE and Social Capital (SC) as regressor delayed by one year, we get a positive and significant coefficient for capital. This seems to indicate that the company expects a development period to see how consumers react against social exclusion. Based on this trend, the company creates a product, which generates demand for critical consumption.

\section{Conclusions}

Our work has verified whether certain business performance measures are influenced by the company's responsible corporate behavior and certifications. Our paper introduces two major novelties in economic literature. The first is the introduction of a sample that intersects two of three international indices (FTSE4Good Index, World Domain Dow Jones Sustainability Index, Domini 400 Social Index) by building only one CSR. We first showed some simple descriptive statistics then we used econometric approaches with panel data and cross sections. To eliminate endogenous problems we used the method of instrumental variables. 
First, we have shown and interpreted the correlation between the collected variables. Another novelty of our work was to focus on the Market Value Added as a measure of business performance. This indicator has been compared with accounting and market-based measures.

The main result is that MVA increases when CSR is reduced. Although this result seems to contradict some previous studies showing higher value of MVA for CSR companies, if we analyse better and more in depth the dynamics, we can observe how over time the number of CSR enterprises has increased, thus reducing the number of non-CSR companies. This migration moves non-CSR companies with low MVA in the CSR group. Therefore, the average value of the MVA of the CSR group is reduced as evidenced by the negative sign of the regression.

Further results from the panel analysis point out that if we use MVA as a business performance measure, the focal point is the evaluation of the enterprises by the investors. An increase in MVA implies that they are "betting" on a certain company.

In this regard, an interesting reflection is about the market structure and whether it is perfect: If it were, or at least from the point of view of CSR, then investors should be able to fully assess the value of a business. This implies that an increase in the value of MVA causes an instant improvement of the company's performance. If the market is not perfect, then investors will bet on the future of businesses. In this second case, the temporal horizon would move from short to medium to long term.

Later, we looked into more detail in the industrial sectors. In addition, we have verified whether some PCP measures, such as the risk level of a share, corporate reputation, and share capital in the country of reference, are linked to CSR.

Subsequently, we pointed out that no econometric analysis can be performed to find an effect of the industrial sectors, as the control sample was defined ad hoc to maintain the sectoral composition of the control sample and the CSR enterprise group homogeneous. However, it appears from the descriptive analysis that the financial sector (bank, insurance, etc.) is the one with the highest CSR percentage, probably because the costs to be incurred in obtaining certification are rather low compared to other sectors.

With regard to the risk factor, our findings seem to be in line with the literature, and point out how it is necessary to focus on timing and heterogeneity of a company to understand the link between risk and CSR. In fact, we cannot support and clearly demonstrate the idea that the strategic choice of getting social certification can reduce the risk. It would also be necessary to carry out medium and long-term analyzes in order to properly verify the effect of certification on the market.

Finally, an interesting development of the analysis could be to compare MVA with a Tobin study, using a real option approach that would seem to be in line with our own results.

Author Contributions: This article is a joint work of the four authors. Cristian Carini contributed to the accounting literature and the theoretical part and to write the paper. Sergio Vergalli participated in the analysis of the results and the theoretical and statistical foundations and contributed to write the paper. Laura Poddi was involved in the conception and design of the paper, the theoretical foundations, data collection and statistical analysis and contributed to write the paper. Nicola Comincioli helped to draft and review the manuscript. All authors participated in the literature review and gave thought to the conclusions.

Conflicts of Interest: The authors declare no conflict of interest.

\section{Appendix A}

In Table A1 the correlations (It has been computed on 2001 data, which is the most representative year. For other correlations, see [12]) between all variables considered are shown. 
Table A1. Correlations (First of all, the correlation coefficient ( $\mathrm{r}$ of Pearson) is low in all cases. Therefore, even if it exists, it is weak. This means that it does not totally explain our phenomenon and therefore we need a more formal model in regression. This could solve the multi-collinearity problem among variables in the model we will look at.)

\begin{tabular}{|c|c|c|c|c|c|c|c|c|c|}
\hline Corr. & CSR & MVA & ROE & Size & Age & Inta & Inte & STLT & GDP \\
\hline CSR & 1 & & & & & & & & \\
\hline MVA & $\begin{array}{r}0.169 \\
(* * *)\end{array}$ & 1 & & & & & & & \\
\hline ROE & 0.002 & 0.0712 & 1 & & & & & & \\
\hline Size & $\begin{array}{c}0.137 \\
(* * *) \\
\end{array}$ & $\begin{array}{c}0.4034 \\
(* * *) \\
\end{array}$ & -0.058 & 1 & & & & & \\
\hline Age & 0.033 & 0.0692 & 0.007 & 0.0473 & 1 & & & & \\
\hline Inta & $\begin{array}{c}0.119 \\
(* *)\end{array}$ & 0.0028 & -0.071 & $\begin{array}{c}0.2522 \\
(* * *)\end{array}$ & $\begin{array}{c}0.169 \\
(* * *)\end{array}$ & 1 & & & \\
\hline Inte & -0.019 & -0.0718 & $\begin{array}{c}0.234 \\
(* * *)\end{array}$ & $\begin{array}{c}-0.097 \\
(*)\end{array}$ & -0.066 & $\begin{array}{c}-0.086 \\
\left({ }^{*}\right)\end{array}$ & 1 & & \\
\hline STLT & 0.032 & 0.0593 & -0.006 & -0.034 & -0.049 & -0.043 & 0.017 & 1 & \\
\hline GDP & 0.040 & 0.0734 & -0.011 & 0.039 & -0.121 & -0.029 & 0.013 & -0.011 & 1 \\
\hline
\end{tabular}

\section{References}

1. Preston, L.E.; O’Bannon, D.P. The Corporate Social-Financial Performance Relationship: A Typology and Analysis. Bus. Soc. 1997, 36, 419.

2. Waddock, S.A.; Graves, S.B. The Corporate Social Performance-Financial Performance Link. Strag. Manag. 1997, 18, 303-319.

3. McWilliams, A.; Siegel, D. Corporate ocial Responsibility: A Theory of the Firm Perspective. Acad. Manag. Rev. 2001, 26, 117-127.

4. Ullmann, A. Data in Search of a Theory: A Critical Examination of the Relationship Among Social Performance, Social Disclosure, \& Economic Performance. Acad. Manag. Rev. 1985, 10, 450-477.

5. Wood, D.J. Corporate Social Performance Revisited. Acad. Manag. Rev. 1991, 16, 691-718.

6. Dahlsrud, A. How Corporate Social Responsibility is Defined: An Analysis of 37 Definitions. Corp. Soc. Responsib. Environ. Manag. 2008, 15, 1-13.

7. Benabou, R.; Tirole, J. Individual and Corporate Social Responsibility. Economica 2010, 77, 1-19.

8. Andries, M. Social Responsibility and Asset Prices: Is There a Relationship? University of Chicago: Chicago, IL, USA, 2008.

9. Dou, J.; Shenghua, J.; Wang, Q. A Meta-Analytic Review of Corporate Social Responsibility and Corporate Financial Performance. Bus. Soc. 2015, 55, 1083-1121.

10. Poddi, L.; Vergalli, S. Does Corporate Social Responsibility Affect The Performance of Firms; Feem Working Paper 52.09; University of Ferrara: Ferrara, Italy, 2009.

11. Comincioli, N.; Poddi, L.; Vergalli, S. Does Corporate Social Responsibility Affect The Performance of Firms; Feem Working Paper No. 52.2009; University of Ferrara: Ferrara, Italy, 2012.

12. Garriga, E.; Mele, D. Corporate Social Responsibility Theories Mapping the Territory. J. Bus. Ethic 2004, 53, $51-71$.

13. KPMG Survay of Corporate Social Responsibility Reporting, 2015. Available online: https://home.kpmg. com/xx/en/home.html (accessed on 3 September 2017).

14. Mattingly, J.E. Corporate Social Performance: A Review of Empirical Research Examining the Corporation-Society Relationship Using Kinder, Lydeberg, Domini Social Ratings Data. Bus. Soc. 2017, 56, 796-839.

15. Van Beurden, P.; Gossling, T. The Worth of Values-A Literatyre Review on the Relation between Corporate Social and Financial Performance. J. Bus. Ethic 2008, 82, 407-424. 
16. Sanchez, J.L.F.; Sotorrio, L.L. Corporate Social Responsibility of the Most Highly Reputed European and North American Firms. J. Bus. Ethic 2008, 82, 379-390.

17. Orlitzky, M.; Schmidt, F.L.; Rynes, S.L. Corporate Social Performance and Firm Risk: A Meta-Analytic Review. Bus. Soc. 2003, 40, 369-396.

18. Kitzmueller, M. Economics and Corporate Social Responsibility; Economics Working Paper; European University Institute: Fiesole, Italy, 2008.

19. Wu, M. Corporate Social Performance, Corporate Financial Performance and Firm Size: A Meta-Analysis. J. Am. Acad. Bus. 2006, 8, 163-171.

20. Singh, P.J.; Sethuraman, K.; Lam, J.Y. Impact of Corporate Social Responsibility Dimensions on Firm Value: Some Evidence from Hong Kong and China. Sustainability 2017, 9, 1532.

21. Charlo, M.J.; Moya, I.; Muñoz, A.M. Financial Performance of Socially Responsible Firms: The Short and Long-Term Impact. Sustainability 2017, 9, 1622.

22. Belghitar, Y.; Clark, E.; Deshmukh, N. Does it pay to be ethical? Evidence from the FTSE4Good. J. Bank. Financ. 2014, 47, 54-62.

23. Curran, M.; Moran, D. Impact of the FTSEGood Index on firm price: An event study. J. Environ. Manag. 2007, 82, 529-537.

24. Collision, D.J.G., Gobb, D.; Power, M.; Stevenson, L.A. The financial performance of the FTSEGood indices. Corp. Soc. Responsib. Environ. Manag. 2008, 15, 1-28.

25. Lopez, V.A.; Garcia, A.; Rodriguez, L. Sustainable Development and Corporate Performance: A study Based on the Dow Jones Sustainability Index. J. Bus. Ethic 2007, 75, 285-300.

26. Searcy, C.; Elkhawas, D. Corporate Sustainability Ratings: An investigation into how corporations use Dow Jones Sustainability Index. J. Clean. Prod. 2012, 35, 79-92.

27. Consolandi, C.; Jaiswal-Dale, A. ; Poggiani, E.; Vercelli, A. Global Standards and Ethical Stock Indexes: The Case of the Dow Jones Sustainability SToxx Index. J. Bus. Ethic 2009, 87, 185-197.

28. Sheldon, O. The Philosophy of Management; Sir Isaac Pitman and Son Ltd.: Emeryville, CA, USA, 1924.

29. Lee, M.-D.P. A review of the theories of corporate social responsibility: Its evolutionary path and the road ahead. Int. J. Manag. Rev. 2008, 10, 53-73.

30. Turker, D. Measuring Corporate Social Responsibility: A Scale Development Stury. J. Bus. Ethic 2008, 85, 411-427.

31. Detomasi, D.A. The Political Roots of Corporate Social Responsibility. J. Bus. Ethic 2007, 82, 807-819.

32. Udayasankar, K. Corporate Social Responsibility and Firm Size. J. Bus. Ethic 2008, 83, 167-175.

33. Chen, H.; Wang, X. Corporate Social Responsibility and Corporate Financial Performance in China: An empirical research from Chinese firms. Corp. Gov. Int. J. Bus. Soc. 2011, 11, 361-370.

34. Quazi, A.; Richardson, A. Sources of variation in linking corporate social responsibility and financial performance. Soc. Responsib. J. 2012, 8, 242-256.

35. Ahmed, W.S.W.; Al-Smadi, A.W. Does Corporate Social Responsibility Lead to Improve in Firm Financial Performance? Evidence from Malaysia. Int. J. Econ. Financ. 2014, 6, 126-138.

36. Whalen, D.J.; Jones, R.E. Stakeholder mismatching: A theoretical problem in empirical research on corporate social performance. Int. J. Organ. Anal. 2013, 3, 229-267.

37. Mallin, C.; Farag, H.; Ow-Yong, K. Corporate Social Responsibility and Financial Performance in Islamic Banks. J. Econ. Behav. Organ. 2014, 103, 21-38.

38. Blasi, S.; Caporin, M.; Fontini, F. A multidimensional analysis of the relationship between Corporate Social Responsibility and Firms' Economic Performance. In Proceedings of the EAERE Conference, Athens, Greece, 28 June-1 July 2017.

39. Teoh, S.H.; Welch, I.; Wazzan, C.P. The Effect of Socially Activist Investment Policies on the Financial Markets: Evidence from the South African Boycott. J. Bus. 1999, 72, 35-89.

40. Choongo, P. A Longitudinal Study of the Impact of Corporate Social Responsibility on Firm Performance in SMEs in Zambia. Sustainability 2017, 9, 1300.

41. Maron, I.Y. Toward a Unified Theory of the CSP-CFP Link. J. Bus. Ethic 2006, 67, 191-200.

42. Beliveau, B.; Cottrill, M.; O'Neill, H.M. Predicting corporate social responsiveness: A model drawn from three perspectives. J. Bus. Ethic 1994, 13, 731-738.

43. Brammer, S.; Millington, A. Firm Size, Organizational Visibility and Corporate Philanthropy: An Empirical Analysis. Bus. Ethic Eur. Rev. 2006, 15, 6-18. 
44. Hillman, A.J.; Keim, G. Shareholder Value, Stakeholder Management, and Social Issues: What's the Bottom Line? Strateg. Manag. J. 2001, 22, 125-139.

45. Johnson, R.A.; Greening, D.W. The Effects of Corporate Governance and Institutional Ownership Types on Corporate Social Performance. Acad. Manag. J. 1999, 42, 564-576.

46. Mahoney, L.S.; Thorne, L. Corporate Social Responsibility and Long-Term Compensation: Evidence from Canada. J. Bus. Ethic 2005, $57,241-253$.

47. Moore, G. Corporate Social and Financial Performance: An Investigation in the U.K. Supermarket Industry. J. Bus. Ethic 2001, 34, 299-315.

48. Belkaoui, A.; Karpik, P.G. Determinants of the Corporate Decision to Disclose Social Information. Account. Audit. Account. J. 1989, 2, 36-51.

49. Brammer, S.J.; Pavelin, S. Corporate Reputation and Social Performance: The Importance of Fit. J. Manag. Stud. 2006, 43, 435-455.

50. Roberts, C. Determinants of Corporate Social Responsibility Disclosure: An Application of Stakeholder Theory. Account. Organ. Soc. 1992, 17, 595-612.

51. Stanwick, P.A.; Stanwick, S.D. The Relation Between Corporate Social Performance, and Organizational Size, Financial Performance, and Environmental Performance: An Empirical Examination. J. Bus. Ethic 1998, 17, 195-204.

52. Adams, M.; Hardwick, P. An Analysis of Corporate Donations: United Kingdom Evidence. J. Manag. Stud. 1998, 35, 641-654.

53. Amato, L.H.; Amato, C.H. The Effects of Firm Size and Industry on Corporate Giving. J. Bus. Ethic 2007, 72, 229-241.

54. Brammer, S.; Cox, P.; Millington, A. An Empirical Examination of Institutional Investor Preferences for Corporate Social Performance. J. Bus. Ethic 2004, 52, 27-43.

55. Brammer, S.; Williams, G.; Zinkin, J. Religion and Attitudes to Corporate Social Responsibility in a Large Cross-Country Sample. J. Bus. Ethic 2007, 71, 229-243.

56. Alexander, G.J.; Buchholz, R.A. Corporate Social Responsibility and Stock Market Performance. Acad. Manag. J. 1978, 21, 479-486.

57. Belkaoui, A.R. The Impact of the Disclosure of the Environmental Effects of Organizational Behavior on the Market. Financ. Manag. 1976, 5, 26-31.

58. Clarkson, M.B.E. A Stakeholder Framework for Analyzing and Evaluating Corporate Social Performance. Acad. Manag. Rev. 1995, 20, 92-117.

59. Harrison, J.S.; Freeman, R.E. Stakeholders, Social Responsibility, and Performance: Empirical Evidence and Theoretical Perspectives. Acad. Manag. J. 1999, 42, 479-485.

60. Kohers, T.; Simpson, W.G. The Link Between Corporate Social and Financial Performance: Evidence from the Banking Industry. J. Bus. Ethic 2002, 35, 97-109.

61. Vance, S.C. Are Socially Responsible Corporations Good Investment Risks? Manag. Rev. 1975, 64, 18-24.

62. Bharadwaj, A.; Bharadwaj, S.G.; Konsynki, B.R. Information technology effects on firm's performance as measured by Tobin's Q. Manag. Sci. 1999, 45, 1008-1024.

63. Konar, S.; Cohen, M.A. Does the Market Value Environmental Performance? Rev. Econ. Stat. 2001, 83, 281-289.

64. Jiang, B.; Belohlav, J.; Young, S.T. Outsourcing impact on manufacturing firm's value: Evidence from Japan. J. Oper. Manag. 2007, 25, 885-900.

65. Shahzad, A.M.; Sharfman, M.P. Corporate Social Performance and Financial Performance: Sample-Selection Issues. Bus. Soc. 2017, 56, 889-918.

66. Surroca, J.; Tribó, J.A.; Waddock, S. Corporate responsibility and financial performance: The role of intangible resources. Strateg. Manag. J. 2010, 31, 463-490.

67. Lindenberg, E.B.; Ross, S.A. Tobin's q ratio and industrial organization. J. Bus. 1981, 54, 1-32.

68. Navarro, P. Why do corporations give to charity? J. Bus. 1988, 61, 65-93.

69. Vishwanatan, M. Curricular Innovations on Sustainability and Subsistence Marketplaces: Philosophical, Substantive and Methodological Orientations. J. Manag. Educ. 2012, 36, 389-427.

70. Quan, X.F.; Wu, S.N.; Yin, H.Y. Corporate Social Responsibility and Stock Price Crash Risk: "Self-interest Tool" or "Value Strategy"? Econ. Res. J. 2015, 11, 49-64.

71. Moskowitz, M. Choosing Socially Responsible Stocks. Bus. Soc. Rev. 1972, 10, 1975. 
72. Patten, D.M. The market reaction to social responsibility disclosures: The case of the Sullivan principles signings. Account. Organ. Soc. 1990, 15, 575-587.

73. Wright, P.; Ferris, S.P. Agency Conflict and Corporate Strategy: The Effect of Divestment on Corporate Value. Strateg. Manag. J., 1997, 18, 77-83.

74. Treynor, J.L. Toward a Theory of Market Value of Risky Assets. In Treynor on Institutional Investing; Wiley: Hoboken, NJ, USA, 1962.

75. Sharpe, W.F. Capital Asset Prices: A Theory of Market Equilibrium Under Conditions of Risk. J. Financ. 1964, 19, 425-442.

76. Lintner, J. The Valuation of Risk Assets and the Selection of Risky Investments in Stock Portfolios and Capital Budgets. Rev. Econ. Stat. 1965, 47, 13-37.

77. Mossin, J. Equilibrium in a Capital Asset Market. Econometrica 1966, 34, 768-783.

78. Spicer, B.H. Investors, Corporate Social Performance and Information Disclosure: An Empirical Study. Account. Rev. 1978, 53, 94-111..

79. Richardson, A.J.; Welker, M.; Hutchinson, I. Managing Capital Market Reactions to Corporate Social Responsibility. In. J. Manag. Rev. 1999, 1, 17-43.

80. Botosan, C.A. Disclosure Level and the Cost of Equity Capital. Account. Rev. 1997, 72, 323-349.

81. Bowman, E.H.; Haire, M.A. Strategic Posture Toward Corporate Social Responsibility. Calif. Manag. Rev. 1975, 18, 49-58.

82. Bragdon, J.H.; Marlin, J.T. Is Pollution Profitable? Risk Manag. 1972, 19, 9-18.

83. Parket, R.; Eilbirt, H. Social Responsibility: The Underlying Factors. Bus. Horiz. 1975, 18, 5-11.

84. Preston, L.E. Analyzing corporate social performance: Methods and results. J. Contemp. Bus. 1978, 7, $135-150$.

85. Cowen, S.S.; Ferreri, L.B.; Parker, D.B. The Impact of Corporate Characteristics on Social Responsibility Disclosure: A Typology and Frequency-Based Analysis. Account. Organ. Soc. 1987, 12, 111-122.

86. De Massis, A.; Kotlar, J.; Campopiano, G.; Cassia, L. The impact of family involvement on SMEs' performance: Theory and evidence. J. Small Bus. Manag. 2015, 53, 924-948.

87. Aupperle, K.E; Carroll, A.B.; Hatfield, J.D. An Empirical Examination of the Relationship between Corporate Social Responsibility and Profitability. Acad. Manag. J. 1985, 28, 446-463.

88. Luce, R.A.; Barber, A.E.; Hillman, A.J. Good Deeds and Misdeeds: A Mediated Model of the Effect of Corporate Social Performance on Organizational Attractiveness. Bus. Soc. 2001, 40, 397.

89. Simerly, R.L.; Li, M. Corporate Social Performance and Multinationality, A Longitudinal Study, 2001. Working Paper. Available online: http//www.westga.edu/ bquest/2000/corporate.html (accessed on 3 September 2017).

90. Cochran, P.L.; Wood, R.A. Corporate Social Responsibility and Financial Performance. Acad. Manag. J. 1984, 27, 42-56.

91. Dierkes, M.; Preston, L. Corporate Social Accounting Reporting for the Physical Environment: A Critical Review and Implementation Proposal. Account. Organ. Soc. 1977, 2, 3-22.

92. Patten, D.M. Exposure, Legitimacy, and Social Disclosure. J. Account. Public Policy 1991, 10, $297-308$.

93. Capelle-Blancard, G.; Petit, A. The Weighting of CSR Dimensions: One SIze Does Not Fit All. Bus. Soc. 2017, 56, 919-943.

94. Kimberly, J. Organizational size and the structuralist perspective: A review, critique, and proposal. Admin. Sci. Q. 1976, 21, 571-597.

95. Roberts, J. The manufacture of corporate social responsibility: Constructing corporate sensibility. Organization 2003, 10, 249-265.

96. Wood, D. Social Issue in Management: Theory and Research in Corporate Social Performance. J. Manag. 1991, 17, 383-406.

97. Myers, S. Determinants of Corporate Borrowing. J. Financ. Econ. 1977, 5, 147-175.

98. Wallace, R.S.O.; Naser, K.; Mora, A. The Relationship Between the Comprehensiveness of Corporate Annual Reports and Firm Characteristics in Spain. Account. Bus. Res. 1994, 25, 41-53.

99. Jensen, M.C., Meckling, W.H. Theory of the firm: Managerial behavior, agency costs and ownership structure. J. Financ. Econ. 1976, 3, 305-360.

100. Ahamed, K.; Courtis, J.K. Associations between corporate characteristics and disclosure levels in annual reports: A meta-analysis. Br. Account. Rev. 1999, 31, 35-61. 
101. Barnea, A.; Rubin, A. Corporate Social Responsibility as a Conflict between Owners; Working Paper Series, No. 20; Center for Responsible Business, University of California, Berkeley: Berkeley, CA, USA, 2005.

102. Rost, K.; Ehrmann, T. Reporting Biases in Empirical Management Research: The Example of Win-Win Corporate Social Responsibility. Bus. Soc. 2017, 56, 840-888.

103. Fombrun, C.J.; Shanley, M. What's in a name? Reputation building and corporate strategy. Acad. Manag. J. 1990, 33, 233-258.

104. Bourdieu, P. The forms of capital. In Handbook of Theory and Research for the Sociology of Education, Richardson, J.G., Ed.; Greenwood: New York, NY, USA, 1985; pp. 241-258.

105. Coleman, J.S. Foundations of Social Theory; Harvard University Press: Cambridge, MA, USA, 1990.

106. Putnam, R. Making Democracy Work Civic Traditions in Modern Italy; Princeton University Press: Princeton, NJ, USA, 1993.

107. Fukuyama, F. Trust: The Social Virtues and the Creation of Prosperity; Free Press Paperbacks: New York, NY, USA, 1995.

108. Guiso, L.; Sapienza, P.; Zingales, L. Cultural Biases in Econimic Exchange. Q. J. Econ. 2009, 124, $1095-1131$.

109. Alesina, A.; La Ferrara, E. Participation in Heterogeneous Communities. Q. J. Econ. 2000, 115, 847-904.

110. McGuire, J.B.; Sundgren, A.; Schneeweis, T. Corporate Social Responsibility and Firm Financial Performance. Acad. Manag. J. 1988, 31, 854-872.

111. Newell, P. From Responsibility to Citizenship: Corporate Accountability for Development. IDS Bull. 2002, 33, 1-12.

112. Jenkins, R. Corporate Codes of Conduct: Self Regulation in a Global Economy; United Nations Research Institute For Social Development: Geneva, Switzerland, 2001.

113. Poddi, L. Responsabilità Sociale e Performance d'Impresa: Un'analisi empirica. Ph.D. Thesis, Università di Ferrara, Ferrara, Italy, 2005.

114. Spence, D.B. Corporate Social Responsibility in the Oil and Gas Industry: The Importance of Reputational Risk. Chicago-Kent Law Rev. 2010, 86, 59.

115. Hilman, H.; Gorondutse, A.H. Relationship between perceived ethics and Trust of Business Social Responsibility (BSR) on performance of SMEs in Nigeria. Middle East J. Sci. Res. 2013, 15, 36-45.

116. Saeidi, S.P.; Sofian, S.; Saeidi, P.; Saeidi, S.P.; Saaeidi, S.A. How does corporate social responsibility contribute to firm financial performance? The mediating role of competitive advantage, reputation, and customer satisfaction. J. Bus. Res. 2015, 68, 341-350.

117. Kaplan, R.S.; Norton, P.D. The Balanced Scorecard-Measures That Drive Performance. Harv. Bus. Rev. 1992, 70, 71-79.

118. Smith, N.C. Corporate Social Responsiblility: Whether or How? Calif. Manag. Rev. 2003, 45, 52-76.

119. Holweg, M.; Pil, F. The advantages of thinking Small. MIT Sloan Manag. Rev. 2003, 44, 33-39.

120. Peloza, J. Using corporate social responsibility as insurance for financial performance. Calif. Manag. Rev. 2006, 48, 52-72.

121. Porter, M.E.; Kramer, M.R. Creating Shared Value. Harv. Bus. Rev. 2011, 89, 62-77.

122. McGuire, J.B.; Schneeweis, T.; Branch, B. Perceptions of firm quality: A cause or result of firm performance. J. Manag. 1990, 16, 167-180.

123. Hart, S.L.A. Natural-Resource-Based View of the Firm. Acad. Manag. Rev. 1995, 20, 986-1012.

124. Porter, M.E.; Kramer, M.R. The Competitive Advantage of Corporate Philanthropy. Harv. Bus. Rev. 2002, 80, $56-68$.

125. Verschoor, C.C. More evidence of better financial performance. Strateg. Financ. 2003, 5, 18-20.

(c) 2017 by the authors. Licensee MDPI, Basel, Switzerland. This article is an open access article distributed under the terms and conditions of the Creative Commons Attribution (CC BY) license (http:// creativecommons.org/licenses/by/4.0/). 